\title{
Factors associated to the adherence to the non-pharmachological treatment of hypertension in primary health care
}

\author{
Fatores associados à adesão ao tratamento não medicamentoso da hipertensão na atenção primária
}

Factores relacionados a la adhesión al tratamiento no medicamentoso de la hipertensión en la atención primaria

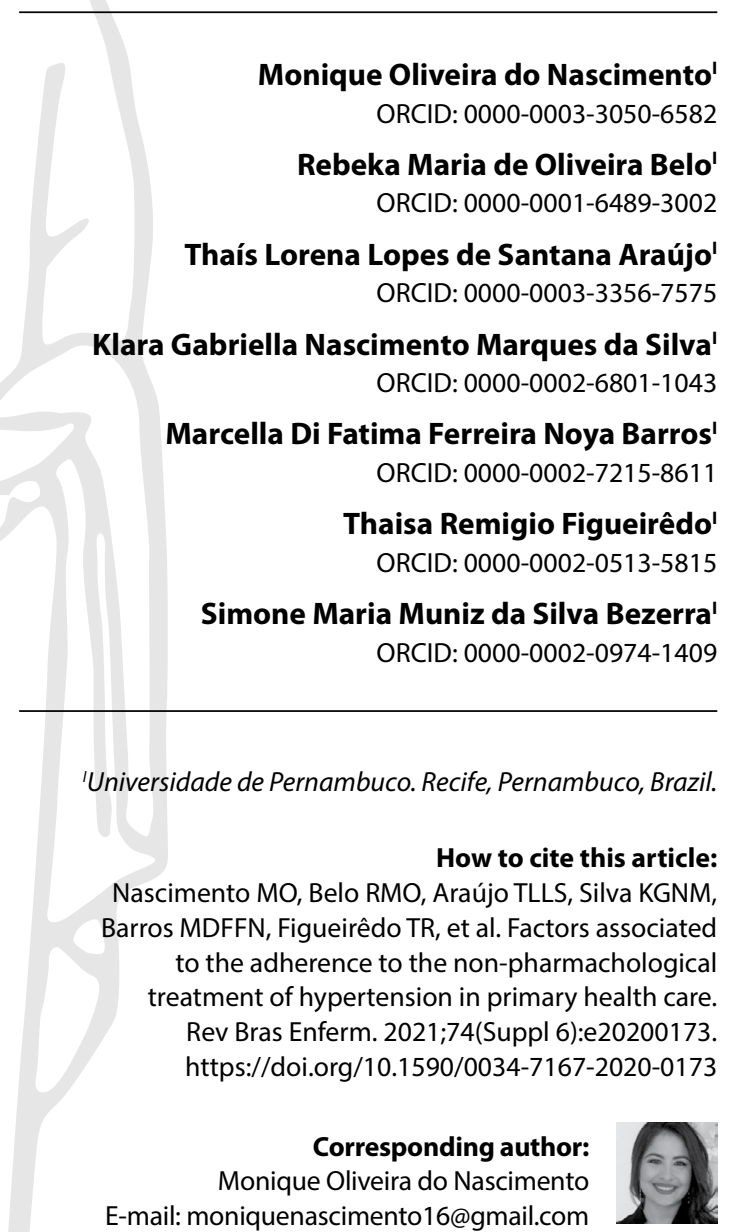

EDITOR IN CHIEF: Dulce Barbosa ASSOCIATE EDITOR: Rafael Silva

Submission: $07-10-2020$

Approval: 05-09-2021

\section{ABSTRACT}

Objectives: to evaluate the factors associated to the adherence to the non-pharmacological treatment of hypertension in primary health care. Methods: cross-sectional study with 421 participants. The adherence was evaluated using the components: weight control, abdominal circumference, physical activity, and alcohol consumption. The chi-squared and Mann-Whitney's tests were used for analysis. Results: the adherence to the control of the abdominal circumference was associated to smoking, sex, and stress. Smoking, age, and profession were associated to weight control. The adherence to a physical activity varied between the sexes and between people who used beta blockers and those who did not. Moderate alcohol consumption was associated to sex, age, profession, income, comorbidities, time using antihypertensive drugs, and using other medication. Conclusions: socioeconomic and clinical factors were associated to the adherence to the anti-hypertensive treatment. Innovative techniques, such as the transtheoretical model of change, motivational interviews, and supported self-care can help in behavioral changes.

Descriptors: Hypertension; Public Health Nursing; Treatment Adherence and Compliance; Primary Health Care; Patient Compliance.

\section{RESUMO}

Objetivos: avaliar os fatores associados à adesão ao tratamento não medicamentoso da hipertensão na Atenção Primária. Métodos: estudo transversal, com 421 indivíduos. Avaliou-se a adesão pelos componentes: controle de peso, circunferência abdominal, atividade física e consumo alcoólico - conforme recomendações da 7a Diretriz Brasileira de Hipertensão Arterial. Na análise, utilizaram-se os testes qui-quadrado e Mann-Whitney. Resultados: a adesão ao controle de circunferência abdominal associou-se ao tabagismo, sexo e estresse. Tabagismo, idade e atividade laboral foram associados ao controle de peso. A adesão à atividade física variou entre os sexos e entre indivíduos que usavam ou não betabloqueadores. $O$ consumo alcoólico moderado associou-se ao sexo, idade, atividade laboral, renda, comorbidades (diabetes mellitus e tabagismo), tempo de tratamento antihipertensivo e uso de outros fármacos. Conclusões: fatores socioeconômicos e clínicos associaram-se à adesão ao tratamento anti-hipertensivo. Técnicas inovadoras como o modelo transteórico de mudança, entrevista motivacional e autocuidado apoiado podem auxiliar as mudanças comportamentais.

Descritores: Hipertensão; Enfermagem em Saúde Pública; Cooperação e Adesão ao Tratamento; Atenção Primária à Saúde; Cooperação do Paciente.

\section{RESUMEN}

Objetivos: evaluar factores relacionados a adhesión al tratamiento no medicamentoso de hipertensión en Atención Primaria. Métodos: estudio transversal, con 421 individuos. Evaluó la adhesión por los componentes: control de peso, circunferencia abdominal, actividad física y consumo de alcohol - conforme recomendaciones de la 7a Directriz Brasileña de Hipertensión Arterial. Análisis se utilizaron los testes chi-cuadrado y Mann-Whitney. Resultados: adhesión al control de circunferencia abdominal relacionado al tabaquismo, sexo y estrés. Tabaquismo, edad y actividad laboral fueron relacionados al control de peso. Adhesión a actividad física varió entre los sexos y entre individuos que usaban o no beta-bloqueadores. Consumo de alcohol moderado relacionado al sexo, edad, actividad laboral, renta, comorbilidades (diabetes mellitus y tabaquismo), tiempo de tratamiento antihipertensivo y uso de otros fármacos. Conclusiones: factores socioeconómicos y clínicos relacionados a adhesión al tratamiento antihipertensivo. Técnicas innovadoras como el modelo transteórico de cambio, entrevista motivacional y autocuidado apoyado pueden auxiliar los cambios comportamentales. Descriptores: Hipertensión; Enfermería en Salud Pública; Cumplimiento y Adherencia al Tratamiento; Atención Primaria de Salud; Cooperación del Paciente. 


\section{INTRODUCTION}

The adherence to a health treatment prescribed is an essential element for a successful therapy ${ }^{(1)}$. Adherence is here understood as the degree to which the behavior of a person is in accordance with the guidance of a health professional, regarding the use of medication, the attention to a diet, or Lifestyle Changes (LSC) ${ }^{(2)}$.

Not adhering to the treatment of noncommunicable diseases (NDs) has been a challenge for public health both in high-income countries and in those with medium-to-low income ${ }^{(3)}$ In the Brazilian setting, the low adherence is associated to a context of demographic and epidemiological transition of the population. In this regard, the aging of the population has reflected in an increased prevalence of NDs ${ }^{(1)}$.

The arterial hypertension (AH) stands out among NDs due to its high prevalence and to the fact that it is a risk factor for the development of cardiovascular diseases and their complications ${ }^{(4-5)}$. Furthermore, the $\mathrm{AH}$ is one of the chronic conditions that generates the highest number of consultations in health services, especially in the Primary Health Care $(\mathrm{PHC})^{(6)}$.

As in other NDs, the AH is not only problematic due to its epidemiological data and to its high prevalence. In this context, the low adherence to antihypertensive treatment has been a reason for a growing preoccupation in dealing with the disease, since it leads to uncontrolled pressure levels and undesirable cardiovascular complication $s^{(7)}$.

The concept of "therapeutic adherence" is usually attributed to pharmacological therapy, as opposed to being used in a broader manner that includes behaviors related to lifestyle. However, the treatment of hypertension also involves non-pharmacological measures, such as weight and abdominal circumference control, adequate diet, practice of physical activities, and limited alcohol consumption $^{(4-5)}$.

Considering these aspects, the $\mathrm{PHC}$ is the adequate level of health care to manage $\mathrm{AH}$ cases, especially from the perspective of non-pharmacological treatment, that is, of a treatment that requires a biopsychosocial approach to the users that involves their beliefs, motivations, and the barriers that prevent them from becoming an actor of their own care ${ }^{(8)}$. However, the daily work of primary care to hypertensive people is marked by providing prescriptions, new or repeated, an by activities of education in health that are disciplinary, preventing an effective therapeutic communication and the consequent adherence to the therapy ${ }^{(9)}$.

Therefore, it is valid to state that the adherence to the treatment to the non-pharmacological treatment of $\mathrm{AH}$ is extremely relevant to be studied in $\mathrm{PHC}$, due to its complexity and subjectivity. This work seeks to understand its determinants and project paths that can deal with this issue, in the search for better clinical results.

\section{OBJECTIVES}

To evaluate the factors associated to the adherence to nonpharmacological hypertension treatments in the context of primary health care.

\section{METHODS}

\section{Ethical aspects}

This study was carried out following the ethical precepts for researchers with human beings and was approved by the Research Ethics Committee from the Universidade de Pernambuco.

\section{Design, period, and place of study}

Cross-sectional quantitative study, developed from November 2018 to January 2019 in the city of Recife, in the state of Pernambuco (PE). The population of the city was estimated in 1,617,183 people in 2015 , with a total of 642,856 people with hypertension registered in this year ${ }^{(10-11)}$. The PHC of the city, in 2017, covered $73 \%$ of the city, with 130 family health units, which are made up by 276 family health teams, 56 teams of the community health agent strategy, 20 teams of the center for the support of family health, and 2 teams for street consultations ${ }^{(12)}$.

This study followed the STROBE protocol for cross-sectional studies.

\section{Population or sample; criteria of inclusion and exclusion}

The population was formed by people with hypertension whose follow up was done in the PHC.

The city is divided in 8 sanitary districts. Two units from each district were chosen randomly for the selection of participants and data collection, a total of 16 units. The draw included units from every district to guarantee that all had a chance of being drawn and to be one of the settings of the research.

Sample calculation was done using the software Epi Info (version 7.2). Considering the estimated number of people with hypertension in the city in 2015, as well as the prevalence of the event, which is $15.9 \%{ }^{(13)}$, in addition to a confidence interval of $95 \%$, a sample error of $5 \%$, and a design effect of 2.0 , the necessary number of hypertensive people in the sample would be 410 . However, to guarantee a higher margin of participants, in order to compensate for potential losses, 421 hypertensive people were included. They were chosen by convenience, as long as they attended to the following inclusion criteria: having $\mathrm{AH}$, being under clinical follow up in the $\mathrm{PHC}$, and being 18 years old or older. The study did not include people who, due to cognitive limitations, were incapable of providing their consent to participate in the study or to answer the questions of the interview.

\section{Study protocol}

The study counted on a script for data collection that included one sociodemographic instrument and one clinical instrument, both elaborated by the researchers, in addition to an instrument for the evaluation of the adherence of participants to nonpharmacological therapies. The latter included the following parameters of non-pharmacological treatment, as recommended by the 7th Brazilian Guideline on Arterial Hypertension: weight and abdominal circumference $(\mathrm{AC})$ control, the practice of physical activity, and alcohol consumption ${ }^{(4)}$. The anthropometric measurements of participants were verified; then, they were asked about the two other components. The cutoff points to classify 
the adherence to the components were registered, according to the recommendations of the guideline ${ }^{(4)}$.

People whose BMI was below $25 \mathrm{~kg} / \mathrm{m}^{2}$ (below 65 years old) or whose BMI was below $27 \mathrm{~kg} / \mathrm{m}^{2}$ (above 65 years old) were considered to adhere to the component "weight control". The adherence to the control of $A C$ was found to be true when it was below $80 \mathrm{~cm}$ for women and below $94 \mathrm{~cm}$ for men.

Concerning physical activity, the study considered as active those who practiced moderate physical activities ( $\geq 30$ minutes/ day, continuously our accumulated, from five to seven days a week), aerobic training ( $\geq 30$ minutes/day, at least three times a week), or resistance training (twice or three times a week, with 8 to 10 muscle-training exercises in series from 10 to 15 repetitions with pauses of up to two minutes).

Regarding alcohol consumption, men who ingested up to two doses a day, and women and low-weight people who ingested up to one dose a day were found to be following recommendations. One does means approximately $14 \mathrm{~g}$ of ethanol, that is, about $350 \mathrm{ml}$ of beer, $150 \mathrm{ml}$ of wine, or $45 \mathrm{ml}$ of distilled beverages ${ }^{(4)}$.

In addition to these measures, pressure was controlled by three measurements of arterial pressure in the office, using an automatic sphygmomanometer. The systolic pressure recorded was the mean of these three different measurements.

To minimize assessment bias in the variables, thus guaranteeing the quality of the data collected, a protocol was elaborated to standardize the application of collection instruments, also standardizing the collection of data about arterial pressure, weight, height, and AC. The interviewees were trained to follow the protocol and were periodically supervised in the field of data collection with no previous warning.

\section{Analysis of results and statistics}

The SPSS software (version 20.0) was used to analyze the data. The statistical test used to verify the relation between some categorical variables was the chi-squared. The odds ratio (OR) was used to estimate relative risk, with an $95 \%$ confidence interval $(\mathrm{Cl}$ 95\%). Mann-Whitney's test was used to verify potential associations between the control of arterial pressure and the components of non-pharmacological adherence.

\section{RESULTS}

The socioeconomic and clinical characterization of participants is described in Table 1.

The medians of systolic and diastolic arterial hypertension among participants (min. and max. values) were of 138 (97-224) and 83 (54-148), respectively. Although these median values are below $140 / 90 \mathrm{mmHg}$, it was possible to find that, in more than half the sample (214), the pressure levels were above borderline values.

There was also a clear predominance of nutritional disturbances associated to obesity and overweight. Furthermore, the abdominal circumference had a median of $100 \mathrm{~cm}$ for women, varying from $58 \mathrm{~cm}$ to $141 \mathrm{~cm}$, with a mean of $101( \pm 11) \mathrm{cm}$ in men.

The main self-reported conditions in the participants were: stress (69.6\%), dyslipidemias (46.1\%), diabetes mellitus (35.4\%), alcoholism (16.4\%), cardiopathy (11.9\%), smoking (11.4\%), stroke (8.6\%), and kidney diseases (6.2\%).
Table 1 - Socioeconomic and clinical characterization of people with hypertension followed up in primary health care, $(\mathrm{N}=421)$, Recife, Pernambuco, Brazil, 2018

\begin{tabular}{|c|c|c|}
\hline Variables & $\begin{array}{c}\text { Mean }( \pm S D) / \text { Median } \\
\text { (min.-max.) }\end{array}$ & n (\%) \\
\hline Sex & - & \\
\hline Female & & $324(77.0)$ \\
\hline Male & & $97(23.0)$ \\
\hline Age & $59.9( \pm 11)$ & \\
\hline$\leq 65$ years & & $288(68.4)$ \\
\hline$>65$ years & & $133(31.6)$ \\
\hline Ethnicity & - & \\
\hline White & & 95 (22.6) \\
\hline Brown & & $219(51.5)$ \\
\hline Black & & $100(23.8)$ \\
\hline Indian (native) & & $4(1.0)$ \\
\hline Other & & $5(1.2)$ \\
\hline Marital status & - & \\
\hline Has a partner & & $210(49.5)$ \\
\hline Does not have a partner & & $211(50.5)$ \\
\hline Paid work & - & \\
\hline Yes & & $117(27.8)$ \\
\hline No & & $304(72.2)$ \\
\hline Income* & $954.00(0.00-4.950 .00)$ & \\
\hline$\leq 1$ minimum wage & & $252(59.9)$ \\
\hline$>1$ minimum wage & & $169(40.1)$ \\
\hline Educational level & $6(0-17)$ & \\
\hline$\leq 9$ years & & $287(68.2)$ \\
\hline$>9$ years & & $134(31.8)$ \\
\hline Arterial pressure classification & - & \\
\hline Normal & & $55(13.1)$ \\
\hline Borderline & & $150(35.6)$ \\
\hline Stage 1 & & $144(34.2)$ \\
\hline Stage 2 & & $40(9.5)$ \\
\hline Stage 3 & & $30(7.1)$ \\
\hline Does not know & & $2(0.5)$ \\
\hline Body mass index & $29.9(16.5-54.2)$ & \\
\hline Low weight & & $6(1.4)$ \\
\hline Adequate weight & & $70(16.7)$ \\
\hline Overweight & & $148(35.4)$ \\
\hline Obesity & & $194(46.4)$ \\
\hline Does not know & & $3(0.7)$ \\
\hline
\end{tabular}

Time of anti-hypertensive

treatment (in months)

$120(6-784)$

$\leq 60$ months

$>60$ months

$139(33.0)$

$282(67.0)$

Type of anti-hypertensive $\square$

Thiazide diuretics

$247(58.6)$

BRA

224 (53.2)

IECA

$142(33.7)$

Beta blocker

95 (22.6)

BCC

$83(19.7)$

Other diuretics

$21(5.0)$

Use of other medications

Yes

297 (70.5)

$124(29.5)$

Note: *Income in Brazilian reais, considering the Brazilian minimum wage from $2018(R \$ 954,00)$; $\square$ Patients may use more than one type, SD - standard deviation; min. - minimum value; max. maximum value; $A R C$ - angiotensin II receptor antagonist; $A C E I$ - angiotensin converting enzyme inhibitor; $C C B$ - calcium channel blockers.

The frequency of adherence and non-adherence of each of the components evaluated is in Table 2.

Table 3 shows the significant associations in the bivariate analysis of independent variables due to the adherence to the components of a non-pharmacological treatment for $\mathrm{AH}$. 
Table 2 - Distribution of the non-pharmacological adherence of people with hypertension followed up in primary health care, $(N=421)$, Recife, Pernambuco, Brazil, 2018

\begin{tabular}{lc}
\hline Categories & $\mathbf{n}(\%)$ \\
\hline Weight control & \\
Adhered & $97(23.2)$ \\
Did not adhere & $321(76.8)$ \\
Abdominal circumference (AC) control & \\
$\quad$ Adhered & $42(10.0)$ \\
Did not adhere & $377(90.0)$ \\
Physical activity & \\
Adhered & $172(40.9)$ \\
Did not adhere & $249(59.1)$ \\
Limited alcohol consumption & \\
Adhered & $355(84.3)$ \\
Did not adhere & $66(15.7)$ \\
\hline
\end{tabular}

The control of levels of tension was analyzed using systolic and diastolic arterial pressure values. Mann-Whitney's test showed significant variations in the min. and max. diastolic pressure levels between participants who adhered or not to weight control and to a limited consumption of alcohol (Table 4).

\section{DISCUSSION}

The LSCs incorporated to the treatment of $\mathrm{AH}$ are in accordance with the treatment of other chronic conditions, which share the same contextual risk factors ${ }^{(14)}$. In this setting, the $\mathrm{PHC}$, as the coordinator of the health care network, is an essential strategy to consolidate the care model in dealing with chronic conditions in a decentralized and longitudinal way, addressing strategies to combat the low adherence to treatments that demand changes in behavior ${ }^{(15)}$.

Table 3- Adherence to the non-pharmacological treatment and socioeconomic and clinical variables of hypertensive people followed up in primary health care, $(\mathrm{N}=421)$, Recife, Pernambuco, Brazil, 2018

\begin{tabular}{|c|c|c|c|c|c|c|c|}
\hline \multirow{3}{*}{ Variables } & \multicolumn{4}{|c|}{ Adherence } & \multirow{3}{*}{ OR } & \multirow{3}{*}{$\mathrm{Cl} 95 \%$} & \multirow{3}{*}{$p^{*}$} \\
\hline & \multicolumn{2}{|c|}{ Yes } & \multicolumn{2}{|c|}{ No } & & & \\
\hline & $\mathbf{n}$ & $\%$ & $\mathbf{N}$ & $\%$ & & & \\
\hline \multicolumn{8}{|c|}{ Adherence to weight control } \\
\hline \multicolumn{8}{|c|}{ Age } \\
\hline$\leq 65$ years & 42 & 14.7 & 243 & 85.3 & \multirow{2}{*}{0.245} & \multirow{2}{*}{$0.152-0.394$} & \multirow[t]{2}{*}{0.000} \\
\hline$>65$ years & 55 & 41.4 & 78 & 58.3 & & & \\
\hline \multicolumn{8}{|l|}{ Paid work } \\
\hline No & 78 & 25.8 & 224 & $\begin{array}{l}83.6 \\
74.2\end{array}$ & 0.563 & $0.323-0.980$ & 0.040 \\
\hline \multicolumn{8}{|l|}{ Smoking } \\
\hline Yes & 18 & 37.5 & 30 & 62.5 & \multirow{2}{*}{2.210} & \multirow{2}{*}{$1.171-4.171$} & \multirow{2}{*}{0.013} \\
\hline No & 79 & 21.4 & 291 & 78.6 & & & \\
\hline \multicolumn{8}{|c|}{ Adherence to abdominal circumference } \\
\hline \multicolumn{8}{|l|}{ Sex } \\
\hline Female & 20 & 6.2 & 303 & 93.8 & \multirow{2}{*}{0.222} & & \\
\hline Male & 22 & 22.9 & 74 & 77.1 & & $0.115-0.428$ & 0.000 \\
\hline Smoking & & & & & & & \\
\hline Yes & 11 & 23.4 & 36 & 76.6 & & & \\
\hline No & 31 & 8.3 & 341 & 91.7 & 3.361 & $1.558-7.251$ & 0.001 \\
\hline Stress & & & & & & & \\
\hline Yes & 23 & 7.9 & 269 & 92.1 & & & \\
\hline No & 19 & 15.0 & 108 & 85.0 & 0.486 & $0.254-0.929$ & 0.026 \\
\hline Adherence to physical act & & & & & & & \\
\hline Sex & & & & & & & \\
\hline Female & 110 & 34.0 & 214 & 66.0 & 0.290 & $0.181-0.466$ & 0.000 \\
\hline Male & 62 & 63.9 & 35 & 36.1 & 0.290 & $0.181-0.466$ & 0.000 \\
\hline Use of beta blocker & & & & & & & \\
\hline Yes & 27 & 28.4 & 68 & 71.6 & 0.498 & $0.303-0.818$ & 0.005 \\
\hline No & 142 & 44.4 & 178 & 55.9 & 0.498 & $0.303-0.818$ & \\
\hline Adherence to a limited al & & & & & & & \\
\hline Sex & & & & & & & \\
\hline Female & 287 & 88.6 & 37 & 11.4 & 3308 & & - \\
\hline Male & 68 & 70.1 & 29 & 29.9 & 3.308 & $1.902-5 . / 53$ & 0.000 \\
\hline Age & & & & & & & \\
\hline$\leq 65$ years & 233 & 80.9 & 55 & 19.1 & 0382 & & 0005 \\
\hline$>65$ years & 122 & 91.7 & 11 & 8.3 & 0.382 & $0.193-0.13 /$ & 0.005 \\
\hline Paid work & & & & & & & \\
\hline Yes & 88 & 75.2 & 29 & 24.8 & 0.421 & $0.244-0.723$ & 0,001 \\
\hline No & 267 & 87.8 & 37 & 12.2 & 0.421 & & \\
\hline Income & & & & & & & \\
\hline$\leq 1$ minimum wage & 224 & 88.9 & 28 & 11.1 & 2221 & $1361-3957$ & 0002 \\
\hline$>1$ minimum wage & 131 & 77.5 & 38 & 22.5 & 2.221 & $1.361-3.95 /$ & 0.002 \\
\hline Time of anti-hypertens & & & & & & & \\
\hline$\leq 5$ years & 110 & 79.1 & 29 & 20.9 & 0573 & $0335-0979$ & 04040 \\
\hline$>5$ years & 245 & 86.9 & 37 & 13.1 & $0.5 / 3$ & $0.335-0.9 / 9$ & 0.040 \\
\hline
\end{tabular}




\begin{tabular}{|c|c|c|c|c|c|c|c|}
\hline \multirow{3}{*}{ Variables } & \multicolumn{4}{|c|}{ Adherence } & \multirow{3}{*}{ OR } & \multirow{3}{*}{ Cl 95\% } & \multirow{3}{*}{$p^{*}$} \\
\hline & \multicolumn{2}{|c|}{ Yes } & \multicolumn{2}{|c|}{ No } & & & \\
\hline & $\mathbf{n}$ & $\%$ & $\mathbf{N}$ & $\%$ & & & \\
\hline \multicolumn{8}{|c|}{ Use of other medications } \\
\hline Yes & 258 & 86.9 & 39 & 13.1 & \multirow{2}{*}{1.841} & \multirow{2}{*}{$1.069-3.171$} & \multirow{2}{*}{0.026} \\
\hline No & 97 & 78.2 & 27 & 21.8 & & & \\
\hline \multicolumn{8}{|l|}{ Smoking } \\
\hline Yes & 32 & 66.7 & 16 & 33.3 & \multirow{2}{*}{0.310} & \multirow{2}{*}{$0.158-0.605$} & \multirow{2}{*}{0.000} \\
\hline No & 323 & 86.6 & 50 & 13.4 & & & \\
\hline \multicolumn{8}{|c|}{ Diabetes mellitus } \\
\hline Yes & 135 & 90.6 & 14 & 9.4 & \multirow{2}{*}{2.279} & \multirow{2}{*}{$1.217-4.270$} & \multirow{2}{*}{0.009} \\
\hline No & 220 & 80.9 & 52 & 19.1 & & & \\
\hline
\end{tabular}

Table 4 - Evaluation of arterial pressure levels considering the components of the non-pharmacological adherence of people with hypertension followed up in primary health care, $(\mathrm{N}=421)$, Recife, Pernambuco, Brazil, 2018

\begin{tabular}{|c|c|c|c|c|c|}
\hline \multirow{2}{*}{ Variables } & & \multicolumn{2}{|l|}{ SAP } & \multicolumn{2}{|l|}{ DAP } \\
\hline & & Median (min.-max.) & $p^{*}$ & Median (min.-max.) & $p^{*}$ \\
\hline Adherence to weight control & $\begin{array}{l}\text { Yes } \\
\text { No }\end{array}$ & $\begin{array}{l}140(100-212) \\
169(101-224)\end{array}$ & 0.701 & $\begin{array}{l}80(51-116) \\
84(51-148)\end{array}$ & 0.000 \\
\hline Adherence to abdominal circumference & $\begin{array}{l}\text { Yes } \\
\text { No }\end{array}$ & $\begin{array}{c}136(100-212) \\
138(97-224)\end{array}$ & 0.464 & $\begin{array}{l}81(52-110) \\
83(51-148)\end{array}$ & 0.250 \\
\hline Adherence to physical activity & $\begin{array}{l}\text { Yes } \\
\text { No }\end{array}$ & $\begin{array}{c}136(97-224) \\
140(100-212)\end{array}$ & 0.164 & $\begin{array}{l}81(52-148) \\
84(51-118)\end{array}$ & 0.072 \\
\hline Adherence to a limited alcohol consumption & $\begin{array}{l}\text { Yes } \\
\text { No }\end{array}$ & $\begin{array}{c}137(97-213) \\
142(113-224)\end{array}$ & 0.109 & $\begin{array}{l}82(51-123) \\
87(71-148)\end{array}$ & 0.002 \\
\hline
\end{tabular}

Note: SAP - systolic arterial pressure; DAP - diastolic arterial pressure; Min. - minimal value; Max. - maximum value; ${ }^{*}$ Mann-Whitney's test.

The components of the non-pharmacological treatment of depression with the lowest adherence in the sample studied were the control of the $\mathrm{AC}$, weight control, and physical activity. Inadequate anthropometric measurements represent a cardiovascular risk and increase arterial pressure ${ }^{(16-17)}$. Furthermore, these weight and abdominal circumference changes are related to physical inactivity, which is very common among participants.

Regarding the adherence to anthropometric parameters, the association between weight control and older people can be explained by the increased overweight and obesity in the Brazilian population of young adults. Furthermore, there is a tendency of a accentuated decrease in overweight and obesity after 64 years of age ${ }^{(18)}$.

Participants with paid work were associated to the non-adherence to weight control. This is due to the increase in the percentage of overweight and obesity in Brazilians in the economically active age group ${ }^{(19)}$. This association may be connected to a routine that is more directed at the professional life, without prioritizing a healthier lifestyle that can contribute to weight control.

There was also a positive association between smoking and both outcomes of weight and AC control. In this regard, some studies show the effects of nicotine in weight loss, generally due to an increased metabolic rate at rest and to the inhibition of appetite ${ }^{(20-21)}$.

The adherence to AC control was lower between women, with a significant association. This may be related to the higher distribution of adipose tissue and lower muscle mass of women. It can also be related to the increase in weight and abdominal fats after menopause ${ }^{(21)}$.

In this study, stress associated to increased abdominal fat shows that this symptom is, in most cases, coupled with anxiety and depression. This has repercussions for the eating habits and it is common for overweight or obese people, suggesting a relation between stress, compulsion for caloric foods, and excess weight.

When the issue of overweight and obesity is addressed as a public health issue, the discussion cannot be only focused on risk factors related to people and on the non-adherence of people to behavior changes, since, often, there are adverse social and environmental contexts that influence it. Therefore, it is also necessary to discuss this theme taking into consideration the need for intersectoral public policies that go beyond the walls of the health sector. This includes diminishing poverty, social inclusion, and guaranteeing the human right to adequate and healthy meals ${ }^{(22)}$.

The practice of physical activity had an inverse relation with the female sex. This result is similar to that of other studies ${ }^{(18,23-24)}$. It should be highlighted that this could be related to the double work journey of women, who often need to conciliate work activities with domestic chores, which makes it harder for them to have the free time needed for physical exercise ${ }^{(24)}$.

The main obstacles for physical activities in women, according to literature, were the absence of an appropriate place to practice, the lack of company, the lack of energy, and demotivation ${ }^{(25)}$. These obstacles reiterate how important it is to adopt hybrid approaches to promote the practice of physical activities: one directed at the social micro-determinants of health; and another targeted at the transformation of individual behavior.

There was also a inverse relation of the use of beta blockers and the adherence to physical activities, which is justified because, in addition to having a hypotensive effect, this type of medication is recommended to treat electric conduction cardiac disturbances. This pathology can lead to cardiac arrest and, consequently, to an intolerance for physical activity ${ }^{(4,26)}$. 
Finally, the association between makes and the non-adherence to limiting the consumption of alcohol was also reported in another study ${ }^{(21)}$. This finding can be attributed to cultural habits in which men are introduced early to alcohol consumption and to the excessive ingestion of alcohol.

The adherence to a limited consumption of alcohol increased in participants above 65 years old. The same tendency was found in Brazilian elders according to the Surveillance of Risk Factors for NDs, from the Ministry of Health ${ }^{(18)}$.

In the sample studied, the association of paid work and of a higher income to the non-adherence to a limited consumption of alcohol is associated to the fact that these socioeconomic conditions increase the financial dependence and the financial power needed to buy alcoholic beverages ${ }^{(27)}$.

The association of limited alcohol consumption with time of anti-hypertensive treatment may be associated to the fact that, with time, individuals may have a better perception of the positive effects of a reduced alcohol consumption in the arterial pressure levels $s^{(4,27)}$.

Similarly, the use of medication for other chronic diseases was associated to the adherence to a limited consumption of alcohol. This probably happens because alcoholism is a factor that negatively affects multiple chronic conditions, and the coexistence of these conditions with hypertension requires more attention to health management.

An example found in this study of a chronic condition associated to a better adherence to limited alcohol consumption is diabetes mellitus, corroborating the findings of a research about alcohol consumption patters in Brazilian elders ${ }^{(28)}$. This disease increased 2.3 times the likelihood of adhering to limited alcohol consumption. This finding is probably related to the fact that these individuals, since they are diabetic, have been already instructed about the need to avoid alcoholism.

Smoking was also associated to the non-adherence to limited alcohol consumption. This result was also found in a Chinese research ${ }^{(27)}$.

In short, when the systolic and diastolic pressure levels were evaluated, separating participants in groups according to the adherence or non-adherence to pharmacological components, the participants who adhered to the weight control and to a limited alcohol consumption had lower levels of diastolic pressure, reiterating the positive impact of these measures to reduce pressure $^{(4,29)}$.

Considering the treatment of disease from a predominantly pharmacological spectrum is associated to a paradigm of care based on a biomedical monocausal model. This undoubtedly reflects the excessive medicalization of the health-disease process in the management of chronic multifactorial diseases such as $\mathrm{AH}$, even in the scope of $\mathrm{PHC}$, where health care needs the individuals, families, and their community to be the main actors.

Promoting the adherence to the non-pharmacological treatment of $\mathrm{AH}$ by the LSCs means going beyond merely informative and prescriptive educational activities. For the changes in behaviors and lifestyle to take place, the cultural context of the individuals must be considered, as well as their cognitive and emotional dimensions. An essential strategy is encouraging people to translate information by pointing at practical solutions about how to change within their daily routines. Considering this, some technologies, such as the transtheoretical model of change, the motivational interview, and the supported self-care have been recommended as facilitators of the LSC process in the scope of chronic conditions ${ }^{(30)}$.

\section{Study limitations}

Considering the observational design of this study, its results are limited regarding the inference of cause and effect. Therefore, this study generates hypotheses. The fact that the Monitoring of Arterial Pressure in the Ambulatory (MAPA) did not measure arterial pressure was a limitation to be considered, since it may diminish the reliability of the results of pressure control.

\section{Contributions to the field}

Knowing the profile of adherence and non-adherence to the therapy in people with hypertension under the care of the PHC multiprofessional teams makes it possible to identify the factors connected to failure in the treatment. In this team, nurses have the skills to elaborate strategies to prevent risk factors and promote health to deal with the issue of low adherence in $\mathrm{AH}$, since they work in the direct assistance and monitoring of this population. In this process, it is possible to use co-participation, that is, to encourage users to perform self-care and reflect on their health problems.

\section{CONCLUSIONS}

The results of this study show that the following factors are associated to the adherence to a non-pharmacological treatment of hypertension: age, sex, income, paid work, smoking, stress, diabetes mellitus, the use of beta blockers, time under anti-hypertensive treatment, and use of other medication.

In the analysis of the control of tension levels, there were significant differences in the values of diastolic pressure among the participants who adhered to weight control and limited alcohol consumption and those who did not.

The identification of which group of participants was more likely to not adhere to a non-pharmacological treatment reiterates the need to incorporate, to the routine of $\mathrm{PHC}$, innovative practices of care to this population that are effective to promote LSCs. Therefore, this article is expected to encourage new reflections directed at reorienting the model of producing care for people with hypertension, in addition to prescriptive aspects and using techniques such as the transtheoretical model of change, the motivational interview, and the supported self-care.

\section{FUNDING}

The work was extracted from the dissertation - Adherence to antihypertensive treatment and control of blood pressure levels in primary care, presented to the Associate Graduate Program in Nursing at the University of Pernambuco and State University of Paraíba, in 2018. For its implementation, it was financed by a postgraduate scholarship granted by the Coordination for the Improvement of Higher Education Personnel (CAPES). 


\section{REFERENCES}

1. Ministério da Saúde (BR). Secretaria de Ciência, Tecnologia e Insumos Estratégicos. Departamento de Ciência e Tecnologia. Síntese de evidências para políticas de saúde: adesão ao tratamento medicamentoso por pacientes portadores de doenças crônicas [Internet]. Brasília: Ministério da Saúde; 2016 [cited 2018 Sep 05]. Available from: http://bvsms.saude.gov.br/bvs/publicacoes/sintese_evidencias_politicas_ tratamento_medicamentoso.pdf

2. Márquez CE, Márquez RS, Rodríguez GE, Baldonedo SA. [How to assess and to improve adherence in clinical practice?] Hipertens Riesgo Vasc [Internet]. 2017 [cited 2019 Sep 17];34(Supl 1):29-35. Available from: https://www.sciencedirect.com/science/article/abs/pii/S1889183718300618 Spanish

3. Fernandez-Lazaro Cl, García-González JM, Adams DP, Fernandez-Lazaro D, Mielgo-Ayuso J, Caballero-Garcia A, et al. Adherence to treatment and related factors among patients with chronic conditions in primary care: a cross-sectional study. BMC Fam Pract. 2019;20(1):132. https:// doi.org/10.1186/s12875-019-1019-3

4. Malachias MVB, Souza WKSB, Plavnik FL, Rodrigues CIS, Brandão AA, Neves MFT, et al. 7a Diretriz brasileira de hipertensão arterial. Arq Bras Cardiol [Internet]. 2016 [cited 2018 Apr 5];107(Supl.3):1-83. Available from: http://publicacoes.cardiol.br/2014/diretrizes/2016/05 HIPERTENSAO_ARTERIAL.pdf

5. Rêgo AS, Radovanovic CAT. Adherence of hypertension patients in the Brazil's Family Health Strategy. Rev Bras Enferm. 2018;71(3):1093-100. https://doi.org/10.1590/0034-7167-2017-0297

6. Barreto MS, Mendonça RD, Pimenta AM, Garcia-Vivar C, Marcon SS. Non-use of primary care routine consultations for individuals with hypertension. Ciênc Saúde Colet. 2018;23(3):795-804. https://doi.org/10.1590/1413-81232018233.12132016

7. Lima DBS, Moreira TMM, Borges JWP, Rodrigues MTP. Association between treatment compliance and different types of cardiovascular complications in arterial hypertension patients. Texto Contexto Enferm. 2016;25(3):e0560015. https://doi.org/10.1590/0104-07072016000560015

8. Celi L, John V, Pechère-Bertschi A, Zisimopoulou S. [Therapeutic adherence in the treatment of hypertension in primary healthcare]. Rev Med Suisse [Internet]. 2019 [cited 2020 Nov 13];15(668): 1946-9. Available from: https://www.revmed.ch/RMS/2019/RMS-N-668/Adhesiontherapeutique-dans-la-prise-en-charge-de-I-hypertension-arterielle-en-medecine-de-premier-recours French

9. Torres GMC, Figueiredo IDT, Cândido JAB, Pinto AGA, Morais APP, Araújo MFM, et al. Therapeutic communication in the interaction between health workers and hypertensive patients in the family health strategy. Rev Gaúcha Enferm. 2017;38(4):e2016-0066. https://doi. org/10.1590/1983-1447.2017.04.2016-0066

10. Secretaria de Saúde do Recife. Secretaria Executiva de Vigilância à Saúde. População do recife: censo demográfico - 2010 e projeções - 2010 a 2016. Recife, 2010.31p

11. Ministério da Saúde (BR). Secretaria de Saúde do Estado de Pernambuco. Departamento de Informática do SUS - Sistema de Informações Hospitalares do SUS (SIH/SUS) [Internet]. 2015 [cited 2018 Apr 30]. Available from: http://tabnet.saude.pe.gov.br/

12. Secretaria de Saúde do Recife. Secretaria Executiva de Coordenação Geral. Plano Municipal de Saúde 2018 - 2021 [Internet]. 2018 [cited 2020 Nov 13]. Available from: http://www2.recife.pe.gov.br/sites/default/files/plano_municipal_de_saude_2018_2021_vf.pdf

13. Moura AA, Godoy S, Cesarino CB, Mendes IAC. [Factors determining non-adherence to hypertension treatment]. Enferm Glob. 2016;15(3):139. https://doi.org/10.6018/eglobal.15.3.219601 Spanish

14. Doyle SK, Chang AM, Levy P, Rising KL. Achieving health equity in hypertension management through addressing the social determinants of health. Curr Hypertens Rep. 2019;21(8):58. https://doi.org/10.1007/s11906-019-0962-7

15. Pena KS, Rollo RM, Reuter CLO, Santos VCF, Riquinho DL, Ramos AR. Care handover to chronic conditions to regionalized planning. Rev Gaúcha Enferm. 2020;41(esp):e20190168. https://doi.org/10.1590/1983-1447.2020.20190168

16. Nascimento-Souza MA, Lima-Costa MF, Peixoto SV. "A body shape index" and its association with arterial hypertension and diabetes mellitus among Brazilian older adults: National Health Survey, 2013. Cad Saúde Pública. 2019;35(8):e00175318. https://doi.org/10.1590/0102-311X00175318

17. Itoh $\mathrm{H}$, Kaneko $\mathrm{H}$, Kiriyama $\mathrm{H}$, Nakanishi $\mathrm{K}$, Mizuno $\mathrm{Y}$, Daimon $\mathrm{M}$, et al. Effect of body weight change on blood pressure in a Japanese General Population with a Body Mass Index $\geq 22$ kg/m2. Int Heart J. 2019;60(6):1381-6. https://doi.org/10.1536/ihj.19-314

18. Ministério da Saúde (BR). Secretaria de Vigilância em Saúde. Departamento de Análise em Saúde e Vigilância de Doenças não Transmissíveis. Vigitel Brasil 2018: vigilância de fatores de risco e proteção para doenças crônicas por inquérito telefônico: estimativas sobre frequência e distribuição sociodemográfica de fatores de risco e proteção para doenças crônicas nas capitais dos 26 estados brasileiros e no Distrito Federal em 2018 [Internet]. Brasília: Ministério da Saúde; 2019 [cited 2018 Sep 05]. Available from: https://portalarquivos2.saude.gov.br/ images/pdf/2019/julho/25/vigitel-brasil-2018.pdf

19. Morean ME, Wedel AV. Vaping to lose weight: Predictors of adult e-cigarette use for weight loss or control. Addict Behav. 2017;66:55-59. https://doi.org/10.1016/j.addbeh.2016.10.022

20. Liu M, Chuang Key CC, Weckerle A, Boudyguina E, Sawyer JK, Gebre AK, et al. Feeding of tobacco blend or nicotine induced weight loss associated with decreased adipocyte size and increased physical activity in male mice. Food Chem Toxicol. 2018;113:287-295. https://doi. org/10.1016/j.fct.2018.01.058

21. Cardoso FN, Domingues TAM, Silva SS, Lopes JL. Modifiable cardiovascular risk factors in patients with systemic arterial hypertension. Rev Min Enferm. 2020;24:e-1275. https://doi.org/10.5935/1415-2762.20200004 
22. Dias PC, Henriques P, Anjos LA, Burlandy L. Obesity and public policies: the Brazilian government's definitions and strategies. Cad Saúde Pública. 2017;33(7):e00006016. https://doi.org/10.1590/0102-311X00006016

23. Guariguata L, Brown C, Sobers N, Hambleton I, Samuels TA, Unwin N. An updated systematic review and meta-analysis on the social determinants of diabetes and related risk factors in the Caribbean. Rev Panam Salud Publica. 2018;42:e171. https://doi.org/10.26633/ RPSP.2018.171

24. Lima DF, Silva MP, Mazzardo O, Lima LA, Sampaio AA, Anguera MG, et al. Time trends of physical activity in Curitiba, Brazil: 2006-2015. Rev Bras Epidemiol. 2019;22:E190059. https://doi.org/10.1590/1980-549720190059

25. Gomes GAO, Papinib CB, Nakamura PM, Teixeira IP, Kokubun E. Barreiras para prática de atividade física entre mulheres atendidas na Atenção Básica de Saúde. Rev Bras Ciênc Esporte. 2019;41(3):263-70. https://doi.org/10.1016/j.rbce.2018.04.007

26. Oliveira BG, Hohl M, Hino AAF. Barriers associated with physical activity practice during leisure time among elderly with heart failure. Rev Bras Ativ Fís Saúde. 2018;23:e0051. https://doi.org/10.12820/rbafs.23e0051

27. Ji A, Lou P, Dong Z, Xu C, Zhang P, Chang G, et al. The prevalence of alcohol dependence and its association with hypertension: a population-based cross-sectional study4 in Xuzhou city, China. BMC Public Health. 2018;18(1):364. https://doi.org/10.1186/ s12889-018-5276-1

28. Noronha BP, Nascimento-Souza MA, Lima-Costa MF, Peixoto SV. Alcohol consumption patterns and associated factors among elderly Brazilians: National Health Survey, 2013. Ciênc Saúde Colet. 2019;24(11):4171-80. https://doi.org/10.1590/1413-812320182411.32652017

29. Beni Yonis O, Khader Y, Okour A, Al Omari M, Al Quran T, Khassawneh A, et al. High rate of hypertension control among treated patients attending a teaching primary healthcare centre in Jordan. Postgrad Med J. 2019;95(1122):193-7. https://doi.org/10.1136/ postgradmedj-2018-136325

30. Mendes EV. O cuidado das condições crônicas na atenção primária à saúde: o imperativo da consolidação da estratégia da saúde da família [Internet]. Brasília: Organização Pan-Americana da Saúde; 2012 [cited 2020 Dec 15]. Available from: http://bvsms.saude.gov.br/bvs/ publicacoes/cuidado_condicoes_atencao_primaria_saude.pdf 